\section{The relapse of coronary artery disease in patients with dia- betes mellitus at Dr. Ramelan Navy Hospital, Surabaya, Indonesia}

\author{
Priyo Mukti Pribadi Winoto, ${ }^{1}$ Ahsan, ${ }^{2}$ \\ Tina Handayani Nasution ${ }^{2}$ \\ ${ }^{1}$ Nursing and Midwifery Faculty, \\ University of Nahdlatul Ulama, \\ Surabaya; ${ }^{2}$ Faculty of Medicine, \\ Universitas Brawijaya, Indonesia
}

\begin{abstract}
The patients with coronary artery disease are susceptible to experience the relapse so that the control towards the risk factors of coronary artery disease is needed such as a history of hypertension, dyslipidemia, suffering from diabetes mellitus, medication adherence, and history of obesity. This study aimed at knowing the relationship between the risk factor of diabetes mellitus and the relapse of coronary artery disease. This study was an analytical observation by using retrospective cohort The total respondent was 189 people taken by using purposive sampling technique. The finding showed that nearly all patients $(82.5 \%)$ did not suffer from diabetes mellitus, and most of them $(72.5 \%)$ experienced the relapse of CAD. The result of the chi-square analysis showed that the $\mathrm{p}$ value of $0.009<\alpha=0.05$, indicating a significant relationship between Diabetes Mellitus and the relapse of coronary artery disease. The patient with diabetes mellitus has a higher risk of experiencing the relapse of CAD. The nurse should concern and control the risk factors of coronary artery disease that affects the relapse.
\end{abstract}

\section{Introduction}

Coronary Artery Disease (CAD) is one of serious arterial diseases since it can cause mortality to the patient in 24 hours and patients who are still alive will experience high risk of relapse symptoms, serious complications, and the increased risk to sudden death. Based on the Baseline Health Research (Riskesdas) in 2013, it showed that the prevalence of CAD was $1.5 \%$ or around $2,650,340$ people in Indonesia. The prevalence of coronary artery disease in East Java reached about $1.2 \%$ of national incidence of CAD. The result of Baseline Health Research (Riset Kesehatan Dasar) 2013 showed that CAD was at the top 7 in the cat- egory of non-infectious disease in Indonesia with East Java as the region with the highest prevalence of 375,127 people.

The risk factors of CAD include family medical history, age, and gender, which these factors are called as the non-modifiable risk factors (Non-Modifiable). The other risk factors that are modifiable or able to be suppressed to reduce the number of incidence rate and possible to be prevented, cured, and controlled are hypertension, smoking, High Blood Sugar (Diabetes Mellitus), dyslipidemia (abnormal lipid metabolism), obesity, decreasing the physical activities, dietary habit, consuming alcoholic drinks. ${ }^{2,3}$ The preliminary study conducted by the researcher at dr. Ramelan Navy Hospital Surabaya, one of A-type referral hospital in East Java, showed that the average visit per month in the outpatient department or cardiology department of dr. Ramelan Navy Hospital Surabaya in 2017 was 1,545 . The total patient with CAD that was being treated per month was 398 people. Meanwhile, the total patient who suffered from the relapse and the rehospitalization of CHD patients was $42 \%$ or around 167 patients per month. Based on those points above, a study to know the risk factors of diabetes mellitus related to the relapse of CAD is needed. The significance of this study is that it is expected to give information and improve the scientific knowledge, for the society or the further researcher about the risk factors of the type 2 diabetes mellitus related to the relapse of CAD, and it can be used as a guideline to conduct the preventive action toward the incidence of CAD.

\section{Materials and Methods}

This study was conducted at dr. Ramelan Navy Hospital Surabaya during January to June 2018. The type of this study was an analytical observation by using a retrospective cohort study as the approach. The population of this study was all medical records of patients with coronary artery disease who had been treated at dr. Ramelan Navy Hospital Surabaya during January to June 2018 that were 189 medical records in total.

The total sample of this study was 189 patients' medical records. The sampling technique was total sampling. The inclusion criterion of this study was all patients' medical records at dr. Ramelan Navy Hospital Surabaya within January to June 2018 who were diagnosed with CAD and the complete medical record data contained of patients' registration numbers, age, sex, diabetes mellitus (pre-prandial blood sugar level), the diagnosis of CAD and non-CAD. The data that had been collected included the second-
Correspondence: Priyo Mukti Pribadi Winoto, Nursing and Midwifery Faculty, Universitas Nahdlatul Ulama Surabaya, SMEA Street 57, Surabaya, Jawa Timur 60243, Indonesia. Tel. +6231.829.1920 - Fax. +6231.829.8582. E-mail: winoto@unusa.ac.id

Key words: diabetes mellitus, relapse, coronary artery disease.

Acknowledgements: The authors would like to appreciate respondents who were very cooperative and staff at dr.Ramelan Navy Hospital Surabaya, for providing us with all facility that were required. Furthermore, we also express gratitude to the Universitas Brawijaya Malang and Universitas Nahdlatul Ulama Surabaya, for supporting us.

Contributions: the authors contributed equally.

Conflict of interests: the authors declare no potential conflict of interest.

Funding: This project was supported by Universitas Nahdlatul Ulama Surabaya.

Conference presentation: part of this paper was presented at the $3^{\text {rd }}$ International Symposium of Public Health, 2018 October 31 - November 1, Universitas Airlangga, Surabaya, Indonesia.

Dedication: This study is dedicated to all of patient at dr.Ramelan Navy Hospotal Surabaya, and also to nursing science all over the world.

Received for publication: 28 July 2019.

Revision received: 9 September 2019.

Accepted for publication: 15 October 2019.

This work is licensed under a Creative Commons Attribution NonCommercial 4.0 License (CC BY-NC 4.0).

${ }^{(}{ }^{C}$ Copyright: the Author(s), 2019

Licensee PAGEPress, Italy

Journal of Public Health in Africa 2019; 10(s1):1193 doi:10.4081/jphia.2019.1193

ary data taken from medical record data. Data analysis used a Chi-Square test using the SPSS program.

\section{Results and Discussion}

This study was conducted at the medical record unit of dr. Ramelan Navy Hospital Surabaya during January to June 2018. Based on the medical record data retrospectively, it had been collected a total of 189 patients' medical records. 


\section{Univariate analysis}

Based on Table 1, it can be identified that the total number of diabetic patients was 33 patients $(17.5 \%)$ and the total patient who experienced e relapse of CAD was 137 patients $(72.5 \%)$.

\section{Bivariate analysis}

Based on Table 2, there were some respondents who did not suffer from Diabetes Mellitus (DM) and most of them experienced relapse of CAD (68.6\%). Meanwhile respondents who suffer from Diabetes Mellitus (DM), almost all of them experienced relapse of CAD (90.9\%). This finding is supported by the result of the Chisquare test presented above. It has been found out that the Sig. Pearson value of the Chi-Square test is 0.009 which is less than the fault tolerance value $(\alpha)=5 \%$. Therefore, it can be inferred that diabetes relapse of CAD.

\section{Discussion}

Based on Table 2, from 189 respondents, it was found that most respondents who did not suffer from Diabetes Mellitus (DM) experience the relapse of CAD. Meanwhile, almost all of respondents who suffer from Diabetes Mellitus (DM) experienced relapse of CAD. Consequently, by referring to the data, it was found that both respondents who did not suffer from DM and those who suffer from DM have a big difference between the risk of relapse incidence and the relapse of CAD. This statement is supported by the result of the Chi-square test. It was found that the Sig. Pearson value of the Chi-Square mellitus has a significant impact on the

was 0.009 that was less than the fault tolerance values, $(\alpha)=5 \%$. Thus, it can be concluded that diabetes mellitus has a significant impact on the risk of relapse of CAD.

The DM disease mentioned in this study is the condition experienced by the respondents with GDP level > $126 \mathrm{mg} / \mathrm{dl}$ when they are diagnosed with $\mathrm{CAD}$ and the respondents have no history of having GDP level $>126 \mathrm{mg} / \mathrm{dl}^{4,5}$ The patient with diabetes mellitus tends to have atherosclerosis at an earlier age and the disease caused by this condition is spread faster and more severe in diabetic patients than the non-diabetic patients have. Insulin plays a vital role in lipid metabolism and lipid abnormalities are frequently found in patients with diabetes. ${ }^{6}$ The level of serum cholesterol and lipoprotein cholesterol in low density are often higher in patients with diabetes, while the high-density lipoprotein is lower in diabetic patients. 5,7

Diabetic patients tend to suffer from a more severe, progressive, complex, and diffuse pattern of CAD. ${ }^{8}$ Diabetes mellitus is related to the pathological changes in the cardiovascular system in the form of endothelial dysfunction and other kinds of vascular diseases including the risk of coronary artery diseases (CAD).${ }^{9}$ Other complications that will be affected by these conditions include microangiopathy, cardiac fibrosis, and the abnormality of cardiac metabolism. ${ }^{10}$

Diabetes mellitus, despite it is the independent risk factor that affects the relapse of $\mathrm{CAD}$, has a relationship with the abnormality of lipid metabolism, obesity, systemic hypertension, and the increase of thrombogenesis (the increased level of platelet adhesion and the increase of fibrinogen levels. ${ }^{10}$

Table 1. The frequency distribution of respondent based on the risk factors of diabetes mellitus.

\begin{tabular}{llcc}
\hline \multirow{3}{*}{ Diabetes Mellitus } & Description & Frequency & Percentage \\
& Non-Diabetes Mellitus & 156 & $82.5 \%$ \\
& Diabetes Mellitus & 33 & $17.5 \%$ \\
& Total & 189 & $100.0 \%$ \\
The Relapse of Coronary Artery Disease & Non Relapse of CAD & 52 & $27.5 \%$ \\
& CAD Relapse & 137 & $72.5 \%$ \\
& Total & 189 & $100.0 \%$ \\
\hline
\end{tabular}

Table 2. The Result of Crosstabs and Chi-Square Test, the Factors of Suffering from DM and the Relapse of CAD.

\begin{tabular}{|c|c|c|c|c|}
\hline & \multicolumn{3}{|c|}{ The Relapse of Coronary Artery Disease } & Total \\
\hline Non Diabetes Mellitus & $\begin{array}{l}\mathrm{n} \\
\%\end{array}$ & $\begin{array}{l}49 \\
31.4\end{array}$ & $\begin{array}{l}107 \\
68.6\end{array}$ & $\begin{array}{l}156 \\
100.0\end{array}$ \\
\hline Diabetes Mellitus & $\begin{array}{l}\mathrm{n} \\
\%\end{array}$ & $\begin{array}{l}3 \\
9.1\end{array}$ & $\begin{array}{l}30 \\
90.9\end{array}$ & $\begin{array}{l}33 \\
100.0\end{array}$ \\
\hline Total & $\sum_{\%}$ & $\begin{array}{l}52 \\
27.5\end{array}$ & $\begin{array}{l}137 \\
72.5\end{array}$ & $\begin{array}{l}189 \\
100.0\end{array}$ \\
\hline
\end{tabular}

The Result of Chi Square Test. Sig. Pearson of Chi-Square $=0.009$
The result of a long-term coronary artery bypass grafting (CABG) is not good in the diabetic patient, and the diabetic patient experiences the increase of early mortality and the risk of the recurrence of stenosis after coronary angioplasty. ${ }^{8}$

\section{Conclusions}

It can be concluded that nearly half of the total respondent suffers from Diabetes mellitus. Most of the respondents experienced the relapse of coronary artery disease. Therefore, there is a relationship between diabetes mellitus and the relapse of CAD.

\section{References}

1. Kementerian Kesehatan Repubik Indonesia. Riset Kesehatan Dasar. Jakarta: Kementerian Kesehatan RI; 2013.

2. Indrawati L. Analisis Faktor Yang Berhubungan Dengan Kemampuan Pasien PJK Melakukan Pencegahan Sekunder Faktor Risiko Di RSPAD Gatot Soebroto Jakarta 2012. Available from: http://lontar.ui.ac.id /file?file=digital $/ \quad 20313795$ T\%2031743-Analisis faktor text.pdf. Accessed on: 8 August 2018.

3. Supriyono M. Faktor-Faktor Risiko Kejadian Penyakit Jantung Koroner (PJK) Pada Kelompok Usia $<45$ Tahun. (Studi Kasus di RSUP Dr. Kariadi Semarang dan RS Telogorejo Semarang) 2008. Available from: https://pdfs.semanticscholar.org/81dc/eb cfc0e83cbea2cfbca938c61797d3598727 .pdf. Accessed on: 8 August 2018.

4. Davey, P. At a Glance Medicine. Jakarta: Penerbit Erlangga; 2005.

5. Soeharto, I. Penyakit Jantung Koroner dan Serangan Jantung edisi kedua. Jakarta: PT Gramedia Pustaka Utama; 2004

6. Hermawatirisa. Penyakit Jantung Koroner. Jakarta: Kandas Media (Imprint agromedia pustaka); 2014.

7. Karikaturijo. Penyakit Jantung Koroner. Jakarta: Universitas Pembangunan Nasional Veteran; 2010.

8. Norhasimah D. Faktor Risiko Penyakit Jantung Koroner. Jakarta: Widya Medika; 2010.

9. Sitorus RH. 3 Jenis Penyakit Pembunuh Utama Manusia. Bandung: Penerbit Yrama Widya; 2008.

10. Smeltzer CS, Bare GB. Buku Ajar Keperawatan Medikal Bedah Brunner \& Suddarth, Edisi 8. Jakarta: Penerbit Buku Kedokteran EGC; 2012. 